\title{
PROBLEMS AND CAUSES OF MARGINAL NUTRIENT AVAILABILITY IN WINERY WASTEWATER TREATMENT
}

\author{
V. BAKos*, B. Kiss and A. JobBÁGY \\ Department of Applied Biotechnology and Food Science, Budapest University of Technology and Economics, \\ H-1111 Budapest, Szt. Gellért tér 4. Hungary
}

(Received: 2 March 2016; accepted: 15 July 2016)

\begin{abstract}
Winery wastewater treatment plants generally face severe nutrient deficiency, and therefore conventional technologies and supplementary nutrient dosing strategies may fail. The purpose of the paper is to show how traditional way of dosing N-source for marginal availability to nutrient deficient influents results in poorly settling activated sludge regardless of the application of aerated or non-aerated selectors. External N-source calculated for marginal availability resulted in nutrient deficiency due to the relatively high yield experienced ( $0.7 \mathrm{~g}$ biomass $\mathrm{COD} / \mathrm{g}$ substrate $\mathrm{COD})$. In the fully aerated system with overall $\mathrm{N}$-deficiency, rapidly increasing overproduction of extracellular polysaccharide was experienced, leading to SVI (Sludge Volume Index) values up to $600 \mathrm{~cm}^{3} \mathrm{~g}^{-1}$. In the system with the non-aerated selector, initial nutrient deficiency could only be detected in the second reactor. Since neither overgrowth of floc-forming GAOs (Glycogen Accumulating Organisms) nor denitrification could be experienced, the non-aerated reactor operated as low-DO (Dissolved Oxygen) basin, attributing to the drastic overgrowth of filamentous bacteria leading to SVI values $>1000 \mathrm{~cm}^{3} \mathrm{~g}^{-1}$. Since dosing external N-source for marginal availability is likely to cause severe biomass separability problems in activated sludge winery wastewater treatment, either pronounced N-overdosing and pre-denitrification or severe nutrient deficiency and GAO cultivation can rather be recommended.
\end{abstract}

Keywords: external nitrogen source, filamentous bulking, low-DO basin, nutrient deficiency, viscous bulking, winery wastewater

It is widely accepted that microorganisms as living creatures require a certain ratio of carbon source (expressed frequently as COD - Chemical Oxygen Demand, and/or BOD Biochemical Oxygen Demand) to nitrogen and phosphorus sources for their growth. However, it has been pointed out that microbial growth yield may depend on the nature of substrate, the species of organisms and the environment, like media complexity, type of terminal electron acceptor, pH, and temperature (Grady et al., 1999; Jenkins et al., 2004).

While in domestic wastewater treatment shortage of carbon source has been more and more likely to experience (TARDY et al., 2012), shortage of nutrients, i.e. low $\mathrm{N}$ and/or P availability may be characteristic of industrial, especially of food industrial influents. Winery wastewater derives from wine production including the cleaning of the basins, the equipment and the floor, rinsing the transfer lines, washing the barrels, the bottling facilities, and the filtration units, etc. Characteristically, winery wastewater is severely nutrient deficient due to its commonly very low $(<0.05)$ N:COD ratio in general (GRADY et al., 1999). It contains predominantly sugars and organic acids (e.g. acetic acid), however, the composition highly varies from site to site depending on the operational period (i.e. vintage, racking, and bottling) and the kind of wine produced (Mosse et al., 2011). Lack of nutrients may cause enhanced

* To whom correspondence should be addressed. Phone: +36 1463 1243; fax: +36 1463 2794; e-mail: vbakos@mail.bme.hu 
proliferation of filamentous microorganisms (WANNER \& JOBBÁGY, 2014), whereas serious nutrient deficiency may lead to overproduction of extracellular polysaccharide, resulting in slimy, bulking biomass in fully aerobic systems (JoBBÁGY et al., 2002). This viscous bulking, just like the dominance of filaments, i.e. filamentous bulking, deteriorates activated sludge floc structure and leads both to poor separability and hindered settleability (JENKINS et al., 2004). JoвbÁGY and co-workers (2002) proposed and verified in lab-scale and JoBbÁGY and co-workers (2006) observed in full-scale the enhanced growth of glycogen accumulating organisms (GAOs) in activated sludge systems with non-aerated selector under nutrient deficient conditions, and KIss and co-workers (2011) verified the possibility of overcoming severe nutrient deficiency of winery wastewater treatment through application of this technology. The traditional way of eliminating any kinds of nutrient deficiency is dosing external $\mathrm{N}$ and/or P sources (WANNER \& JoBBÁGY, 2014) taking into account the widely used $\mathrm{C}: \mathrm{N}: \mathrm{P}$ ratios of the literature. This technique, however, does not only increase treatment costs, but at the typically fluctuating influent quality may likely end up with under-dosing or possible overdosing creating new problems, e.g. necessity of nitrification and denitrification, that would originally not exist. The purpose of the paper is to draw attention to the fact that the traditional way of overcoming nutrient deficiency through external dosing of $\mathrm{N}$ and/or $\mathrm{P}$ for marginal availability may lead to unexpected nuisances in activated sludge floc structure both in systems with aerated (AE) selectors and in those with non-aerated (NA) selectors.

\section{Materials and methods}

\subsection{Continuous-flow pilot-scale experiment}

During the experiment, two continuous-flow, lab-scale activated sludge wastewater treatment systems (see Fig. 1) were operated simultaneously. Both systems consisted of a selector (2.5 1), a second, aerated main reactor (7 1), and a secondary clarifier (7 1). The systems differed only in the operation of their selectors: in system AE an aerated, whereas in system NA a non-aerated, only stirred selector was applied. For setting the external nutrient dosing into a modelled winery wastewater to a minimum acceptable level, the commonly used ratio of COD:N:P=100:5:1 was applied with setting the P concentration slightly higher (to 1.3). The synthetic influent contained $6.8 \mathrm{~cm}^{3}$ 'BB Szürkebarát demi sec' type of wine/1, $1182 \mathrm{mg}$ sodium acetate $/ 1$ and $0.6 \mathrm{~g}$ sugar/l (sucrose) as carbon source giving a total of $\sim 1900 \mathrm{mg}$ $\mathrm{COD} / \mathrm{l}$. $\mathrm{NH}_{4} \mathrm{Cl}$ was used as nitrogen source at an initial concentration of $95 \mathrm{mg} \mathrm{N} / 1$, increased later to $150 \mathrm{mg} \mathrm{N} / 1$. Phosphorus was dosed in a concentration of $25 \mathrm{mg} \mathrm{K} \mathrm{HPO}_{4} / 1$. Minerals added were $36 \mathrm{mg} \mathrm{CaCl}_{2} / 1$ and $16.5 \mathrm{mg} \mathrm{MgCl}_{2} / 1$. The systems were seeded by an activated sludge mixture deriving from a winery and a municipal wastewater treatment plant in a ratio of 1:1 (expressed in mass of dry solid content).

At a temperature of $21 \pm 1.5{ }^{\circ} \mathrm{C}$, the operation was monitored through the daily measurement of $\mathrm{pH}$ and Dissolved Oxygen (DO) concentration (by WTW Multi 350i portable analyzer) as well as biomass concentration expressed in Mixed Liquor Suspended Solids (MLSS) and the Sludge Volume Index (SVI). Concentrations of Chemical Oxygen Demand (COD), filtered COD, Total Organic Carbon (TOC, Elementar High Temperature TOC/TNb Analyzer), Total Nitrogen (TN), ammonia, nitrate, and nitrite were measured 3 times a week, while phosphate and Total Phosphorus (TP) concentrations were measured twice a week, according to Hungarian standard methods (MSZ 260/3:1973, MSZ ISO 6060:1991, MSZ ISO 7150-1:1992, MSZ 260/10:1985, MSZ 260/11:1971, MSZ EN 25663:1998, MSZ 
260/20:1980). In addition to these commonly investigated parameters, total, intra-, and extracellular carbohydrate concentrations were also investigated by the procedure developed and applied earlier by JoвbáGY and co-workers (2002). Microscopic observations were made under phase contrast and by India ink staining of the sludge samples taken from the main aerated reactors of the systems in order to follow the changes in the biomass composition.

A

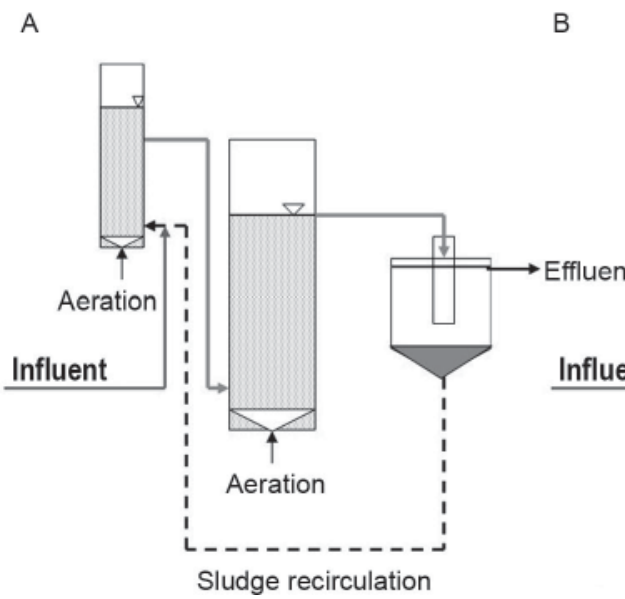

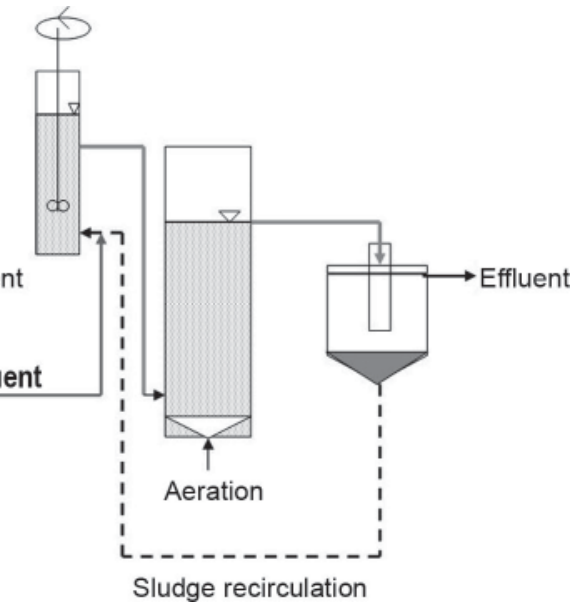

Fig. 1. The schematic of A) the aerated (AE) and B) the non-aerated (NA) selector containing experimental systems

The initial biomass concentrations were set to $6 \mathrm{~g} \mathrm{l}^{-1}$ aiming to reach a high enough biomass retention time that may enable nitrification. The influent flow rate and recirculation rate were both set to $0.5 \mathrm{l} \mathrm{h}^{-1}$, and from the $10^{\text {th }}$ day the latter was increased to $0.751 \mathrm{~h}^{-1}$. The hydraulic retention time (HRT) was initially $16.5 \mathrm{~h}$ and decreased to $13 \mathrm{~h}$ from the $10^{\text {th }}$ day.

\subsection{Calculations for the real nitrogen demand at the higher yield estimated}

As a starting point for calculations of the minimum $\mathrm{N}$ need of biomass growth, Equation 1 has been applied.

$$
\mathrm{Y}=-\mathrm{dx} / \mathrm{dS}
$$

where: $\mathrm{Y}$ is the biomass yield, $\mathrm{dx}$ is the biomass produced by using up $\mathrm{dS}$ amount of assimilated substrate.

The biomass composition was considered as $\mathrm{C}_{5} \mathrm{H}_{7} \mathrm{O}_{2} \mathrm{~N}\left(\mathrm{M}=113 \mathrm{~g} \mathrm{~mol}^{-1}\right)$ and a factor of 1.2 was used as the COD content of $1 \mathrm{~g}$ biomass TSS (Total Suspended Solids) according to GRADY and co-workers (1999). Calculation consisted of the following steps: (i) COD equivalent of $1 \mathrm{~mol}$ biomass was calculated; (ii) Assuming a high yield of $\mathrm{Y}=0.7 \mathrm{~g}$ biomass $\mathrm{COD} / \mathrm{g}$ substrate $\mathrm{COD}$, the produced (newly grown) biomass was calculated on the basis of substrate used up, and expressed in g biomass COD; (iii) According to the produced biomass at this higher yield, the assimilated $\mathrm{N}$ (equal to minimum $\mathrm{N}$ need) was calculated by the use of the above biomass composition. 


\section{Results and discussion}

\subsection{Fully aerated system $(A E)$}

As ammonia concentration dropped down to the threshold of detectability already in the first aerated reactor (see Selector $\mathrm{NH}_{4} \mathrm{~N}$ in Fig. 2A) without nitrate formation, it could be assumed that all of the influent $\mathrm{N}$-source was used up for bacterial growth. This refers to $\mathrm{N}$ shortage compared to the readily biodegradable carbon source available. Taking into account that the model wastewater contained exceptionally well-biodegradable compounds like Na-acetate and sugar, higher than usual values of the true growth yield were assumed to be the reason of the nutrient shortage experienced. There had been earlier references coming to the same conclusions. GRADY and co-workers (1999) published that the COD-based stoichiometric equation for bacterial growth on carbohydrate $\left(\mathrm{CH}_{2} \mathrm{O}\right)$ with ammonia as nitrogen source gives a biomass yield of $0.71 \mathrm{~g}$ biomass COD formed/g carbohydrate COD used. SMETS and co-workwers (1994) published also similarly high yield data for biomass grown on acetate ( $0.74 \mathrm{~g}$ biomass COD/g acetate COD). Applying the calculation steps described in Chapter 1.2. and taking a yield of $\mathrm{Y}=0.7 \mathrm{~g}$ biomass $\mathrm{COD} / \mathrm{g}$ substrate, for the inlet carbon source of $1900 \mathrm{mg} \mathrm{COD} / 1$ removed $137.3 \mathrm{mg} \mathrm{NH} \mathrm{N}_{4} \mathrm{~N} / 1$ proved to be required as N-source for the unlimited bacterial growth. On the basis of the calculations, the COD:N ratio to be applied was shifted up to 100:7.23. The influent ammonia concentration was accordingly increased from $95 \mathrm{mg} \mathrm{N} / 1$ (i.e. approx. $45 \mathrm{mg} \mathrm{N} / 1$ in influent entering the reactors mixed and diluted by recirculation) to $138 \mathrm{mg} \mathrm{N} / 1$ on the $7^{\text {th }}$ day, and in order to be on the safe side, up to $150 \mathrm{mg}$ $\mathrm{N} / 1$ (i.e. $80 \mathrm{mg} \mathrm{N} / 1$ in mixed influent) on the $8^{\text {th }}$ day as illustrated in Figure 2A. Once ammonia concentration had been increased, nitrification started to occur.

The N-deficiency experienced could be assumed to serve as an explanation for deteriorated sludge structure and SVI values increasing up to as high as $600 \mathrm{~cm}^{3} \mathrm{~g}^{-1}$, as illustrated in Figure 3A. Values of total, intra-, and extracellular carbon content (see Fig. 3B) showed that the initial relatively high intracellular carbohydrate content of the biomass decreased to about one half, whereas the relatively low $(5 \mathrm{w} / \mathrm{w} \%)$ extracellular carbohydrate content increased drastically (up to $25 \mathrm{w} / \mathrm{w} \%$ by the $9^{\text {th }}$ experimental day). Comparing Figures $3 \mathrm{~A}$ and $3 \mathrm{~B}$, close connection between extracellular polysaccharide content and SVI values can be observed as it had been pointed out earlier by JoBBÁGY and co-workers (2002). In order to bring the poorly settling sludge back from the clarifier to the reactors, the recirculation rate was increased from $0.51 \mathrm{~h}^{-1}$ to $0.751 \mathrm{~h}^{-1}$ from the $10^{\text {th }}$ experimental day. This resulted in relatively quick increase of biomass concentration in the bioreactors (see Fig. $3 \mathrm{~A})$. However, at the increased biomass concentration, newly increasing SVI values up to $>400 \mathrm{~cm}^{3} \mathrm{~g}^{-1}$ could be detected. These experimental results refer to the fact that once the biomass structure has been deteriorated through overproduction of extracellular polysaccharide caused by nutrient deficiency, even considerably increased influent $\mathrm{N}$-concentration may not bring a quick healing. This can be likely attributed to a hard or impossible transport of nutrients through the thick extracellular polysaccharide layer. In the last week of the experiment, nitrification was detected to be incomplete, as considerable concentrations of nitrite were measured. SVI values started to decrease with increasing biomass concentration, and effluent $\mathrm{NH}_{4} \mathrm{~N}$ concentration decreased to an acceptable level showing safe nutrient availability. 
A

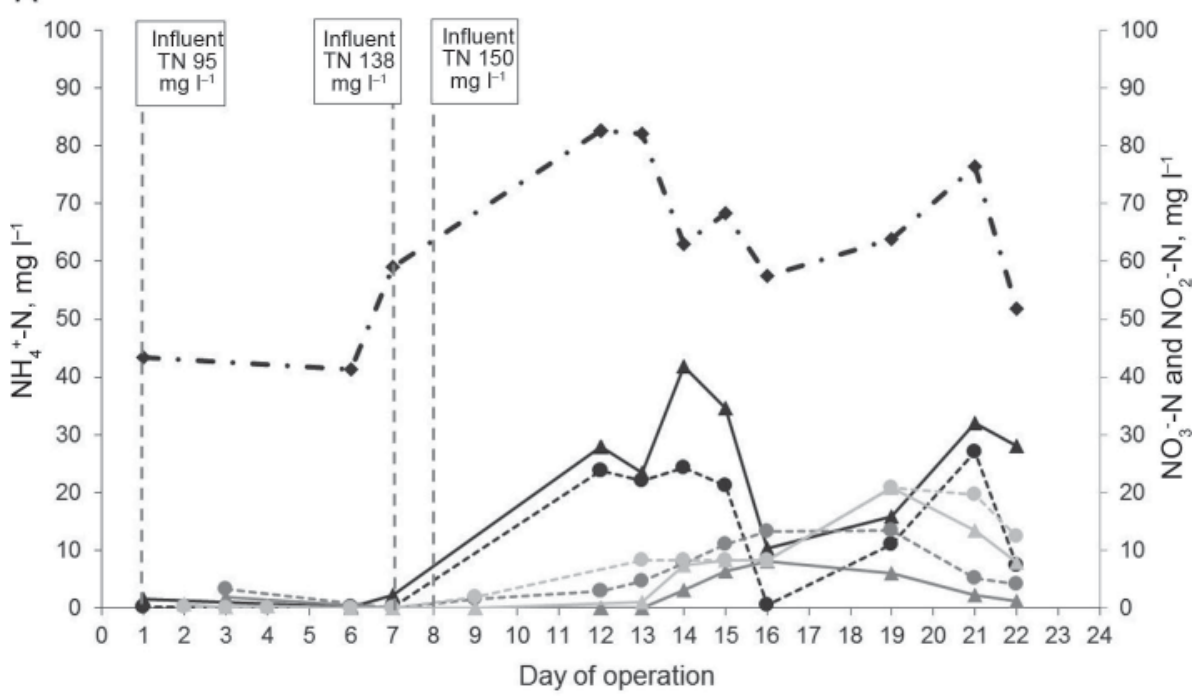

B

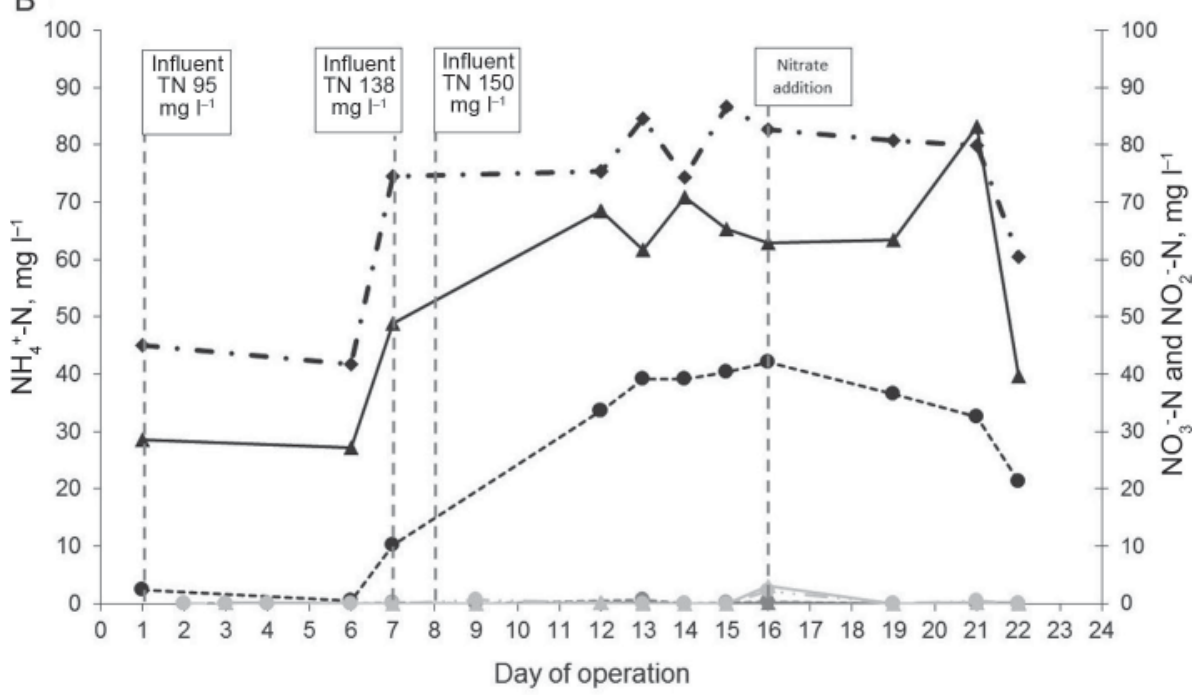

Fig. 2. Nitrogen removal in system A) with aerated selector and B) with non-aerated selector (measurement

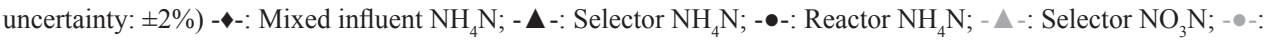
Reactor $\mathrm{NO}_{3} \mathrm{~N}$; - $\triangle-$ : : Selector $\mathrm{NO}_{2} \mathrm{~N} ;-\bullet-$ : Reactor $\mathrm{NO}_{2} \mathrm{~N}$ 


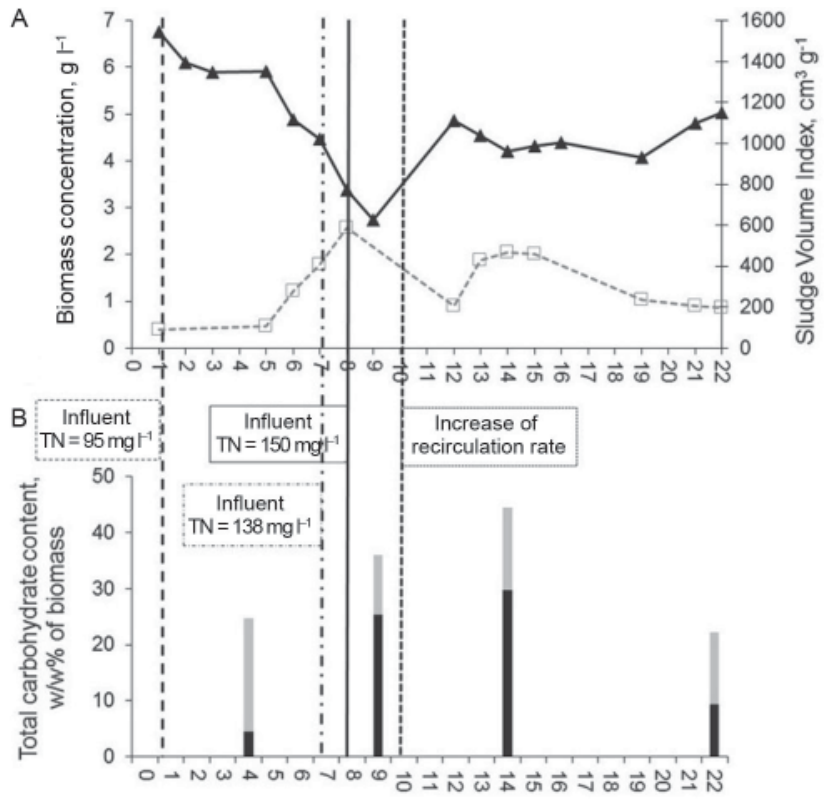

Day of operation

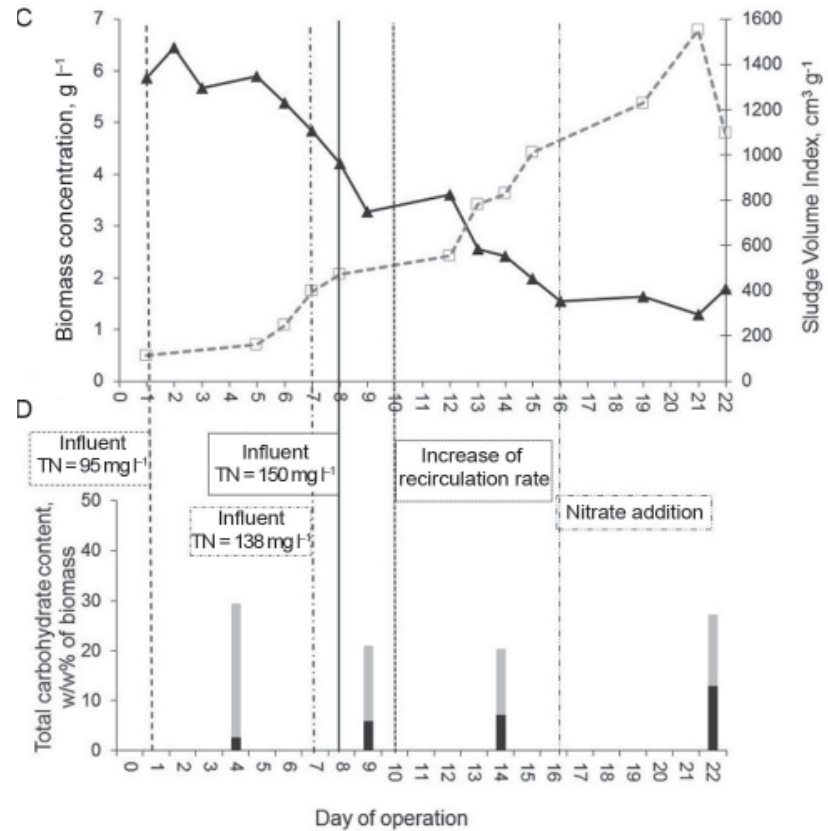

Fig. 3. Biomass concentration, Sludge Volume Index, and total carbohydrate content (including intra- and extracellular, expressed in w/w $\%$ - mass fraction of the biomass) of A-B: the aerated and C-D: the non-aerated selector containing systems (measurement uncertainty: $\pm 5 \%$ ) A and C: - $\mathbf{\Delta}-$-: Biomass concentration; $-\square-$ : Sludge

Volume Index; B and D: | : Extracellular carbohydrate content; | : Intracellular carbohydrate content 
The fully aerated system worked with an average of $95 \%$ COD removal efficiency, which basically occurred in the aerated selector (see Fig. 4), just like the nitrogen and the phosphorous removal, creating low substrate and high dissolved oxygen concentration (low-S and high-DO) conditions (WANNER \& JoBBÁGy, 2014; JoBBÁGY et al., 2015) at marginal availability of nutrients in the whole system, as shown in Table 1 (Section A). This fact led to the failure of the selector effect, and ensured the metabolic advantage of the filamentous organisms instead of floc-forming bacteria, when severe nutrient deficiency could be stopped. The specific growth rates $(\mu)$ of the microorganisms were estimated by Monod kinetics showing filamentous advantage both in the first and in the second reactor (see Table 1, Section A). For these calculations, the kinetic parameter values (maximum specific growth rates and half-saturation coefficients) were applied according to NIEKERK and co-workers (1988) and KAPPELER and GuJer (1994).

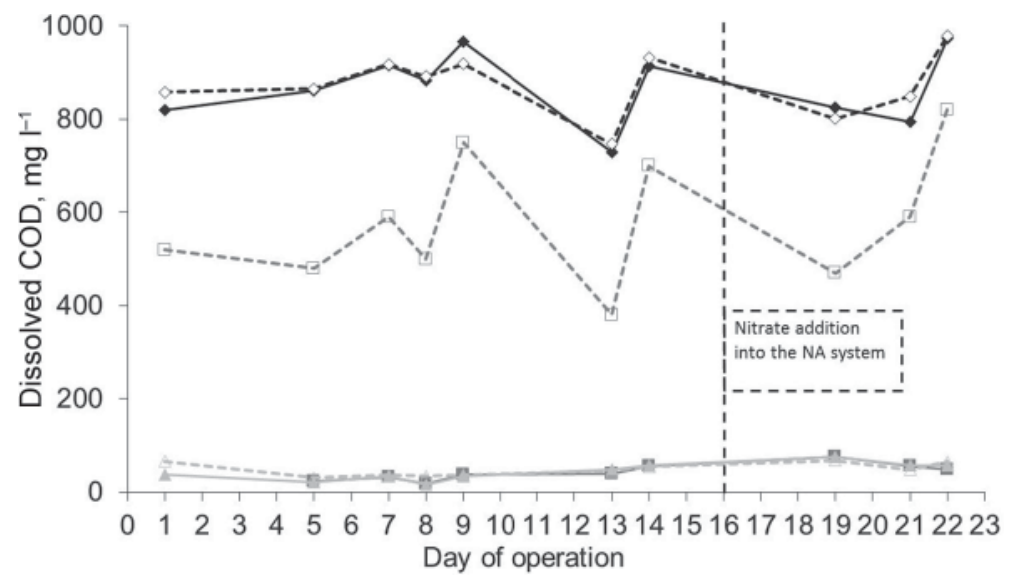

Fig. 4. Carbon removal in the aerated selector (AE) and in the non-aerated selector (NA) containing experimental systems (measurement uncertainty: $\pm 2 \%$ ) - -: AE system mixed influent; $-\diamond-:$ NA system mixed influent; - system selector; - $\square-:$ NA system selector; - $\Delta-$ : AE system reactor; - $\triangle-$ : NA system reactor

\subsection{Non-aerated selector containing system (NA)}

The experimental system with the non-aerated selector showed some typical problems why believed metabolic advantage of floc formers in these bioreactor arrangements may fail in the lack of nitrate as electron acceptor or growth of PAOs (Phosphorous Accumulating Organisms) or GAOs (Glycogen Accumulating Organisms) (JoBBÁGY et al., 2015).

This system provided a COD removal efficiency of about $95 \%$, but just one third of the COD removed was eliminated in the first non-aerated reactor (Fig. 4). As visible in Figure $2 \mathrm{~B}$, there was still relatively high $\mathrm{N}$-availability in the non-aerated reactor, which does not favour growth of GAOs. Moreover, in the selector only minor P release was detected at the beginning of the experiment caused likely by PAOs coming from the seed. However, this PAO activity decreased gradually and disappeared together with the GAOs until the middle of the second experimental week (data not shown). 
Table 1. Calculated specific growth rate values for the floc-forming and filamentous bacteria Section A in the fully aerated system Section B in the non-aerated selector containing system

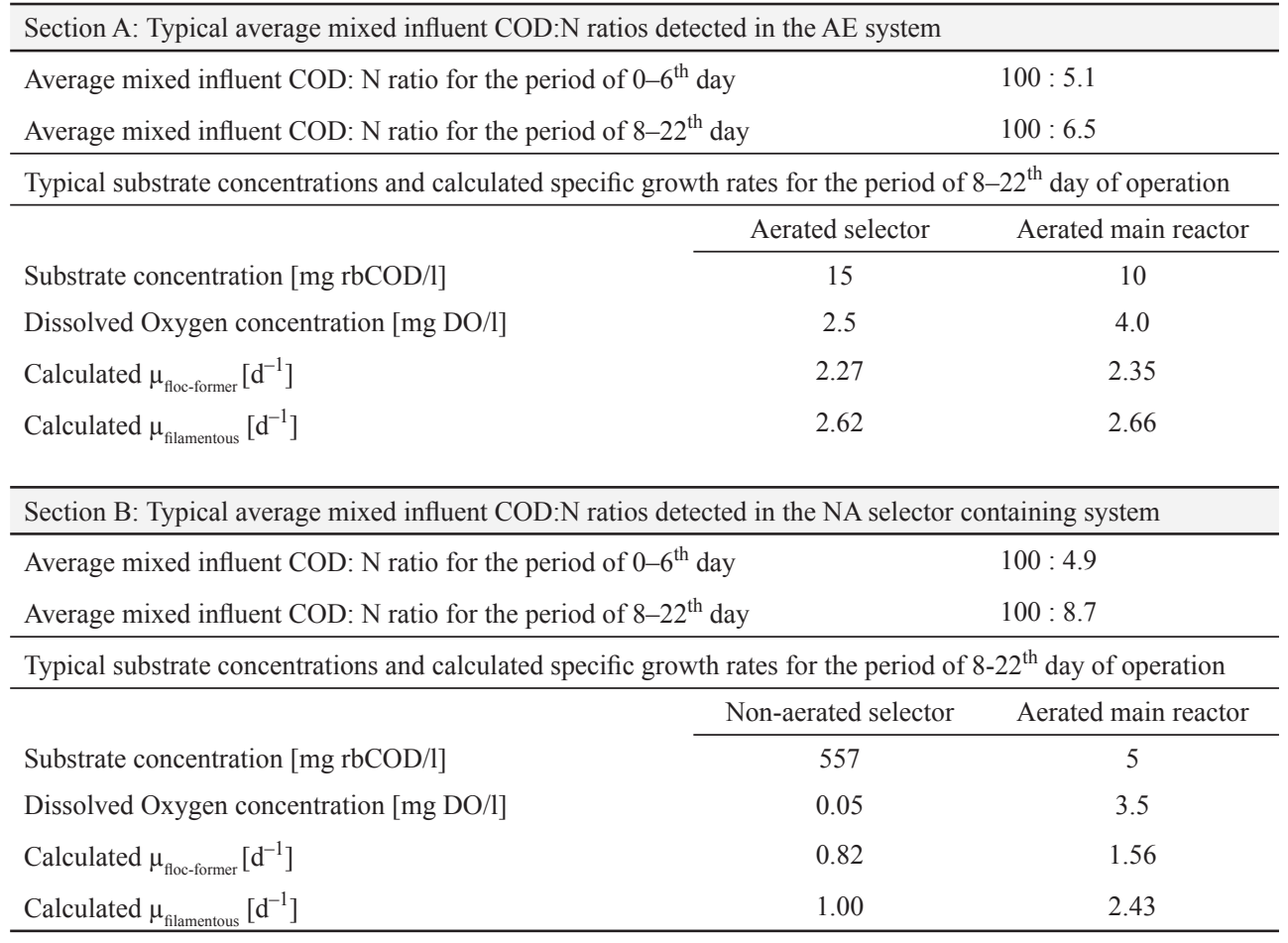

rb: readily biodegradable

Therefore, the non-aerated selector proved to be much rather a high-S - low-DO (between 0-0.2 $\mathrm{mg} \mathrm{DO} / 1$ ) basin, while in the main reactor low-S - high-DO (between 3.5-5 $\mathrm{mg} \mathrm{DO} / \mathrm{l}$ ) conditions were detected favouring the filamentous growth in the whole system (see Table 1, Section B). Comparing the calculated $\mu$ values of Table 1, Sections A and B, the highest growth advantage of filaments can be observed in the second reactor of the system with the non-aerated selector, where the bulk of carbon source was eliminated. In this system, shortage of $\mathrm{N}$-source can only be observed in the main reactor during the startup phase. However, no N-deficiency occurred after increasing the amount of $\mathrm{N}$-source. At the relatively smaller aerobic SRT (Solids Retention Time) no nitrification could be detected.

Despite the relatively higher availability of the $\mathrm{N}$-source, considerable deterioration of the starting floc-structure and drastic increase of the SVI value could be observed also in this system as shown in Figure 3C. However, no drastic increase of extracellular polysaccharide content could be detected (see Fig. 3D). The increased biomass recirculation from the secondary clarifier just helped to temporarily stop loosing sludge from the reactor and increasing SVI values. Long-term stabilization of the system and possible way of improvement was shown by dosing nitrate externally into the non-aerated reactor.

Microscopic observations showed a major presence of filamentous bacteria in the biomass of the non-aerated selector containing system and no excessively produced amount of extracellular polysaccharide. 


\section{Conclusions}

In order to fulfil requirements of bacterial growth, the common practice has been to set the $\mathrm{N}-$ level in nutrient deficient influents to marginal availability. The research verified, however, that external $\mathrm{N}$-source calculated for marginal availability may well prove to be under-dosed, due to the higher than usual bacterial growth yield. Therefore, created marginal availability of $\mathrm{N}$-source is likely to cause severe biomass separability problems in activated sludge plants treating originally nutrient deficient winery wastewater. Either pronounced N-overdosing and pre-denitrification or severe nutrient deficiency and cultivation of GAOs (Glycogen Accumulating Organisms) can rather be recommended.

The research was funded by the Budapest University of Technology and Economics, Dept. Applied Biotechnology and Food Science. The valuable technical support of József Simon is highly acknowledged.

\section{References}

Grady, C.P.L. JR., DaigGer, G.T. \& Lim, H.C. (1999): Biological wastewater treatment. $2^{\text {nd }}$ ed., Marcel Dekker, Inc., New York, Basel. p. 63.

Hungarian Standard (1971): Szennyvizek vizsgálata. Nitrátion meghatározása (Wastewaters analysis. Determination of nitrate ion). MSZ 260-11:1971, 2 pages.

Hungarian STANDARD (1973): Szennyvizek vizsgálata. Oldott és lebegőanyag-tartalom meghatározása (Wastewaters analysis. Determination of dissolved and floating matters). MSZ 260-3:1973, 4 pages.

Hungarian Standard (1980): Szennyvizek vizsgálata. Összes foszfor meghatározása (Wastewaters analysis. Determination of total phosphorus), MSZ 260-20:1980, 2 pages.

Hungarian Standard (1985): Szennyvizek vizsgálata. Nitrition meghatározása (Wastewaters analysis. Determination of nitrite ion), MSZ 260-10:1985, 3 pages.

Hungarian Standard (1991): A viz kémiai oxigénigényének meghatározása (Water quality. Determination of the chemical oxygen demand), MSZ ISO 6060:1991, 6 pages

Hungarian Standard (1992): Az ammónium meghatározása vízben. Manuális spektrofotometriás módszer (Water quality. Determination of ammonium. Part 1: Manual spectrophotometric method). MSZ ISO 7150-1:1992, 8 pages.

Hungarian Standard (1998): Vizminöség. A Kjeldahl-nitrogén meghatározása. Szelénes roncsolás utáni meghatározás (ISO 5663:1984) (Water quality. Determination of Kjeldahl nitrogen. Method after mineralization with selenium (ISO 5663:1984)), MSZ EN 25663:1998, 9 pages.

Jenkins, D., Richard, M.G. \& Daigger, G.T. (2004): Manual on the causes and control of activated sludge bulking and foaming. $3^{\text {rd }}$ edition, CRC Press LLC, Boca Raton, Florida, US, pp. 67-69., p. 103.

JobbÁgy, A., LiterÁthy, B. \& TARdy, G. (2002): Implementation of glycogen accumulating bacteria in treating nutrient-deficient wastewater. Water Sci. Technol., 46, 185-190.

JobbÁgy, A., Literáthy, B., Wong, M-T., Tardy, G. \& Liu, W-T. (2006): Proliferation of glycogen accumulating organisms induced by Fe(III) dosing in a domestic wastewater treatment plant. Water Sci. Technol., 54, 101109.

Jobbágy, A., Weinpel, T., Bakos, V. \& VÁnKos, Zs. (2015): Factors potentially converting non-aerated selectors into "low-S - low-DO basins", effects of seal-covering. $12^{\text {th }}$ IWA Specialised Conference on Design, Operation and Economics of Large Wastewater Treatment Plants, 6-9 September, 2015, Prague, Czech Republic. Proc. pp. 149-155.

Kappeler, J. \& Gujer, W. (1994): Development of a mathematical model for "aerobic bulking”. Water Res., 28, 303-310.

Kiss, B., Bakos, V., Liu, W-T. \& JobBÁgy, A. (2011): Full-scale use of glycogen-accumulating organisms for excess biological carbon removal. Water Environ. Res., 83, 855-864. 
Mosse, K.P.M., Patti, A.F., Christen, E.W. \& Cavagnaro, T.R. (2011): Review: winery wastewater quality and treatment options in Australia, Aust. J. Grape Wine R., 17(2), 111-122.

Niekerk, M.v.A., Jenkins, D. \& Richard, M.G. (1988): A mathematical model of the carbon-limited growth of filamentous and floc-forming organisms in low F/M sludge. Journal (Water Pollution Control Federation), $60,100-106$.

Smets, B.F., Ellis, T.G., Brau, S., Sanders, R.W. \& Grady, C.P.L. JR. (1994): Quantification of the kinetic differences between communities isolated from completely mixed activated sludge systems operated with or without a selector using a novel respirometric method. Water Sci. Technol., 30, 255-261.

TARdy, G.M., BAKos, V. \& JobBÁgy, A. (2012): Conditions and technologies of biological wastewater treatment in Hungary. Water Sci. Technol., 65, 1676-1683.

WAnner, J. \& JobBágy, A. (2014): Activated sludge solids separations. -in: Jenkins, D. \& Wanner, J. (Eds) Activated sludge - 100 years and counting. IWA Publishing, Glasgow, UK. pp. 171-173. 